\title{
Dans l'ombre de Marie-Antoinette, Le Journal de Madame Brunyer
}

\section{Guillaume Mazeau}

\section{(2) OpenEdition \\ 1 Journals}

\section{Édition électronique}

URL : https://journals.openedition.org/ahrf/2013

DOI : 10.4000/ahrf.2013

ISSN : 1952-403X

Éditeur :

Armand Colin, Société des études robespierristes

\section{Édition imprimée}

Date de publication : 1 juin 2005

Pagination : 180

ISSN : 0003-4436

\section{Référence électronique}

Guillaume Mazeau, «Dans l'ombre de Marie-Antoinette, Le Journal de Madame Brunyer », Annales

historiques de la Révolution française [En ligne], 340 | avril-juin 2005, mis en ligne le 20 avril 2006, consulté le 23 avril 2022. URL : http://journals.openedition.org/ahrf/2013 ; DOI : https://doi.org/ 10.4000/ahrf.2013

Ce document a été généré automatiquement le 23 avril 2022.

Tous droits réservés 


\title{
Dans l'ombre de Marie-Antoinette, Le Journal de Madame Brunyer
}

\author{
Guillaume Mazeau
}

\section{RÉFÉRENCE}

Danielle GALLET (éd), Dans l'ombre de Marie-Antoinette, Le Journal de Madame Brunyer, 1783-1792, Paris, CHAN/Honoré Champion, 2003, ISBN 2-7453-0854-8.

1 Conservé aux Archives nationales sous le titre anonyme de Journal des Dépenses d'une dame de la Cour, 1783-1792, le document ici édité et commenté par Danielle Gallet est rendu à son auteur : Madame Brunyer, première femme de chambre de Madame Royale de 1788 à 1791. Le manuscrit, édité dans son intégralité et enrichi d'un intéressant appareil critique (annotations, extrait du manuscrit original sans corrections d'orthographe, fac-similés, et documents complémentaires comprenant des documents familiaux et l'interrogatoire fait après Varennes), offre aux chercheurs plusieurs sources d'intérêt. Il sera particulièrement utile aux amateurs d'histoire matérielle: livre de comptes avant tout, il ne laisse pas de place aux épanchements personnels ni aux considérations politiques. Au cœur même des événements révolutionnaires, la liste de courses remplace ici logiquement le «rien» du journal de chasse royal. Outil d'économie domestique, il dévoile néanmoins des aspects de l'histoire économique et culturelle de la fin du XVIIIe siècle, et témoigne de l'évolution des rapports sociaux dans l'entourage proche de la famille royale au cœur de la période révolutionnaire. L'actualité politique nationale affleure parfois et le livre de compte peut devenir journal intime : on y trouve un nouveau témoignage (non utilisé par Timothy Tackett) sur la préparation de la « fuite à Varennes » et ses conséquences sur l'entourage royal. En nous renseignant sur le déclin de la société de Cour, le journal de madame Brunyer permet donc aussi d'apercevoir, par l'escalier de service, la chute de la monarchie. 